\title{
PHOTOVOLTAIC SYSTEMS WITH VERTICALLY MOUNTED BIFACIAL PV MODULES IN COMBINATION WITH GREEN ROOFS
}

\author{
Thomas Baumann ${ }^{1,+}$, Hartmut Nussbaumer ${ }^{1}$, Markus Klenk ${ }^{1, *}$, Andreas Dreisiebner ${ }^{2}$, Fabian \\ Carigiet $^{1}$, Franz Baumgartner ${ }^{1}$ \\ 1 Zurich University of Applied Sciences, SoE, Institute of Energy Systems and Fluid \\ Engineering, Technikumstrasse 9, CH-8401 Winterthur, Switzerland \\ ${ }^{2}$ Solarspar, Bahnhofstrasse 29, $\mathrm{CH}-4450$ Sissach, Switzerland \\ 'phone: +41 58934 7187, 'e-mail: thomas.baumann@zhaw.ch \\ *phone: +41 58934 4804, *e-mail: markus.klenk@zhaw.ch (corresponding author)
}

Abstract Dependent on the specific conditions flat roofs can be well suited for the installation of large photovoltaic systems in urban areas. For urban designers also other aspects, such as the insulation of buildings, cooling, air purification and water retention play an important role besides the ecological energy generation. The combination of photovoltaics and roof greening can therefore be an interesting fusion. It combines the advantages of a green roof with the local electrical energy production at the place of consumption.

However, using a conventional photovoltaic system with tilted modules in south or east-west direction on a green roof causes problems, as typical low tilt angels and high ground coverage rates result in an almost complete coverage of the roof surface. Plants, growing in between the covered areas provoke undesirable shading of the collector surface. Only a frequent maintenance procedure, complicated by dense PV system layouts, can avoid a reduction of the energy yield in the course of time.

Vertically mounted specially designed bifacial modules are an option to realize photovoltaic power generation in combination with a functional green roof at low maintenance costs. In this paper, we report on the layout and the energy yield of a corresponding system. Custommade bifacial modules with 20 cells were produced and vertically installed in landscape orientation. The narrow layout of the modules lowers the wind load and reduces the visibility. The enhanced power in the morning and evening of vertically east-west installed modules can additionally lead to higher self-consumptions rates.

Despite having some shading and undergrounds with albedo factors of less than 0.2 , the bifacial installation with a rated power of $9.09 \mathrm{kWp}$ achieved a specific yield of the $942 \mathrm{kWh} / \mathrm{kWp}$ in one year (11.08.2017 to 10.08.2018). This is close to typical values of 1000 $\mathrm{kWh} / \mathrm{kWp}$ achieved for south-facing PV systems in the same region.

The impact of the greening on the albedo and the system performance is investigated in more detail with two smaller sub-systems. The energy yields of the two bifacial sub-systems are compared to a monofacial, south-facing reference module. The use of silver-leaved plants in this system resulted in higher albedo values and a more resilient roof greening.

Keywords: PV system; green roof; bifacial; urban areas; vertical; albedo 


\section{Nomenclature}

PV Photovoltaic

GCR

Ground cover ratio [\%]

SGR Standard green roof

BGR

Bright green roof

Wp

STC

spectra)

LED
Nominal module or system power as measured at STC conditions [W]

Standard testing conditions $\left(25^{\circ} \mathrm{C} ; 1000 \mathrm{~W} / \mathrm{m}^{2} ; \mathrm{AM} 1.5\right.$, defined

\section{Introduction}

Green roofs promise a wide range of benefits compared to other flat roof solutions such as the reduction of peak water runoff (water retention), protection of the roof seal, additional insulation, cooling and air humidification of the ambient atmosphere, habitat for animals (especially insects), filtering air pollutants and other effects. Currently, building regulations that support the green roof concept are being implemented around the world (Snow, 2016). These regulations aim to reduce rainwater runoff, to improve air quality and to reduce the need for cooling (Azeñas et al., 2018). Sealed floor surfaces in cities, waste heat from houses and engines enhance the warming of the air during the day and reduce the cooling of the air during night. Thus, summer nights in cities are four to five degrees warmer compared to rural regions (Soukup and Häne, 2015). The maximum cooling at street level due to green roofs ranges from 0.03 to $3{ }^{\circ} \mathrm{C}$ according to 17 studies that provide data on urban heat island reduction (Francis and Jensen, 2017). Due to tremendous cost reductions in the past decades, photovoltaic energy is going to be one of the major energy contributors of electrical energies. Roofs in urban areas are predestinated for the use of photovoltaic energy conversion as unused area can be used meaningfully and the produced energy can at least partly be used directly at the place of the consumer. It is therefore a logical approach to combine both solutions to one urban roof concept.

In real applications however, the combination of a photovoltaic (PV) system with green roof creates obstacles, which make such a solution unfavorable. Today's PV installations on green roofs largely cover the flat roof area, which suppresses the green roof effect to a large extent, if not bitumen or gravel is used from the outset. Plants often lead to considerable shading of the modules, while on the other hand the green roof maintenance is hindered by the PV installation. A green roof layout with good accessibility for maintenance lowers the ground cover ratio (GCR) of the PV system and reduces the annual yield.

Vertically mounted bifacial modules may be an option to provide sufficient area for the plants and their maintenance in combination with a PV system giving specific energy yields comparable to standard flat roof systems. Simulations of vertically mounted bifacial modules have shown that this installation type has the potential to produce higher specific energy yields as compared to standard installations. The actual yield is however also extremely 
dependent on the location and on the installation conditions (Guo et al., 2013; Nussbaumer et al., 2015). An important factor for the output of vertically installed bifacial systems is the mutual shading by adjacent rows, which requires a large row distance and low GCR to limit the shadowing losses.

In this work, the concept of a PV system with vertically mounted bifacial modules in combination with a green roof is demonstrated by a realized example. The achieved energy yield of two different grounds is analyzed and compared to the energy yield of a southorientated monofacial reference module. In addition, simulations with PVSyst were carried out for several configurations with varying GCR and albedo values. In order to appraise the accuracy of the simulations, the calculated results for the two specific systems are compared to measured data.

\section{PV System design and measurement set-up}

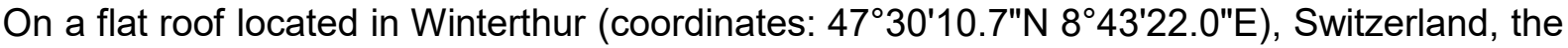
Solarspar association installed a bifacial PV system with $9.09 \mathrm{kWp}$ nominal power. The modules are mounted vertically with an orientation close to the east-west direction $\left(90^{\circ}\right.$ tilt angle, $-65^{\circ}$ azimuth for the front side and $115^{\circ}$ for the rear side) as shown in Figure 1 . Due to the building orientation the alignment of the system is, compared to a perfect east-west orientation, rotated by $25^{\circ}$ (Figure 2). The roof is divided into several fields with different soil material and plants. Two subfields are analyzed in more detail. In these two fields, respectively two modules in the center of each specific field are measured as representative examples for typical modules in an extended system. In an extended system with vertically installed modules, mutual shading is an important factor. Modules at the rim of a field are less affected by shading and including them leads to an overestimation of the typical yield.

One of the two test fields consists of a standard green roof substrate and a standard mixture of green-leaved plants (standard green roof, SGR). The other consists of recycled green roof substrate combined with bright gravel and silver-leaved plants to achieve a higher albedo (bright green roof, BGR) as proposed by Wassmann-Takigawa (Muntwiler et al., 2019). Figures 2 and 3 show the location and details of the subsystems. Silver-leaved plants are found in dry environments with high solar irradiation. The bright color of the plants protects them from drying out by partially reflecting the sunlight. Accordingly, they also have an improved resilience in dry conditions. Plants with a low growth height were deliberately selected. The green roof was not watered in the reported period, but relied on precipitation as a moisture source.

A single, monofacial standard module is installed in south direction (16 $6^{\circ}$ tilt angle, $25^{\circ}$ azimuth) as reference. Mutual shading effects that would occur in an extended PV system are not considered in this stand-alone configuration, but should be small for this installation type with low tilt angle. The arrangement on the roof is shown in the aerial view in figure 2.

Due to the pronounced self-shading effects of vertically installed modules, module based MPP trackers were installed. This setup allows a monitoring of the energy yield of the whole field. An AC electricity meter measures the feed-in of the entire PV system. The meter reading was read periodically and evaluated for a period of one year ( $11^{\text {th }}$ August 2017 to $10^{\text {th }}$ August 2018). The specific energy yield of the $9.09 \mathrm{kWp}$ vertical bifacial PV system in this period is $942 \mathrm{kWh} / \mathrm{kWp}$. A typical value for south-facing PV systems in the same region is $1000 \mathrm{kWh} / \mathrm{kWp}$ (Baumann et al., 2018).

As described above the energy yield is monitored with increased accuracy for respectively 
two modules in the center of two sub-field with differing ground. High quality DC power measurement systems are installed to monitor these two modules in each sub-field and the monofacial reference module (in total five modules). The measurement uncertainty for the power measurement is below $0.5 \%(\mathrm{k}=2)$ and the measurements are logged every 10 seconds. The module temperature of the reference module is measured with a Class $A$ PT1000 sensor mounted on the module backside. The measurement uncertainty of the temperature sensor depends on the actual temperature resulting in $\pm 0.25^{\circ} \mathrm{C}(\mathrm{k}=2)$ at $50{ }^{\circ} \mathrm{C}$. The used measurement electronics in the data logger add another $\pm 0.25^{\circ} \mathrm{C}$ measurement uncertainty $(\mathrm{k}=2)$.

The bifacial PV system was put into operation in March 2017 and the south-facing reference module was installed in spring 2018. The more precise DC power measurement of the five modules (reference module plus four bifacial modules in the two specific fields SGR and BGR) was started on 19 May 2018. For this work, measurement data until the $18^{\text {th }}$ of September have been taken into account. Therefore, four months or 123 days of measurement data have been evaluated. Data of the electricity meter for the whole system have been available since July 2017.

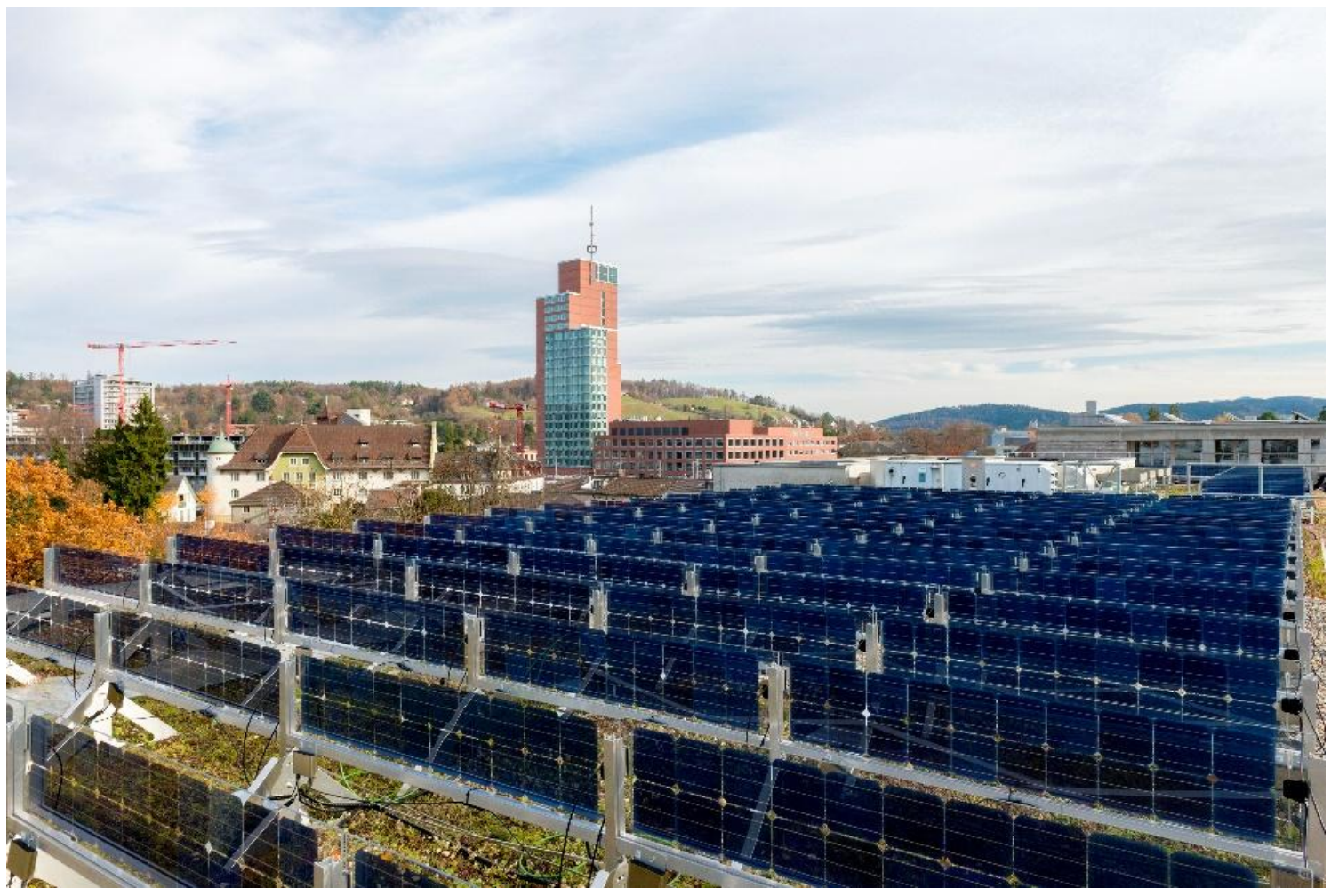

Figure 1 Vertically east-west oriented bifacial modules were installed on the green roof in Winterthur, Switzerland with a nominal power of $9.09 \mathrm{kWp}$. The east-west-facing modules have a tilt angle of $90^{\circ}$ and an azimuth angle of $-65^{\circ}$ for the front side and $115^{\circ}$ for the rear side. (Used azimuth angle definition: east $=-90^{\circ}$, south $=0^{\circ}$ and west $=90^{\circ}$ ) 


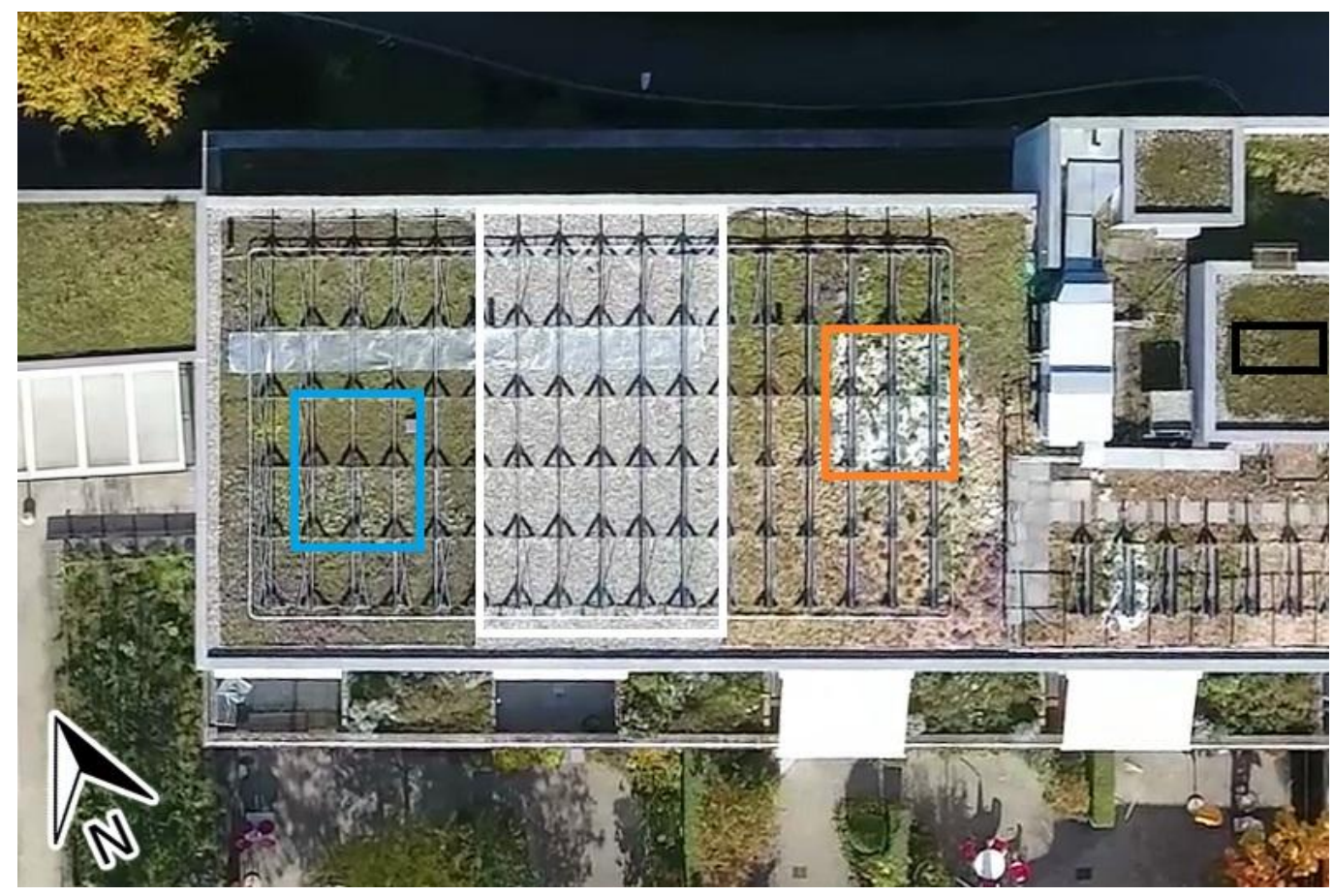

Figure 2 Aerial view of the roof. Power measurements with increased precision were performed on respectively two modules in the center of fields marked with orange and blue color rectangles. The monofacial south-oriented reference module (not shown on the photo) is located in the area marked with the black rectangle. The ground in the area within the white rectangle is covered with gravel. Due to the building orientation the alignment of the system is, compared to a perfect east-west orientation, rotated by $25^{\circ}$.
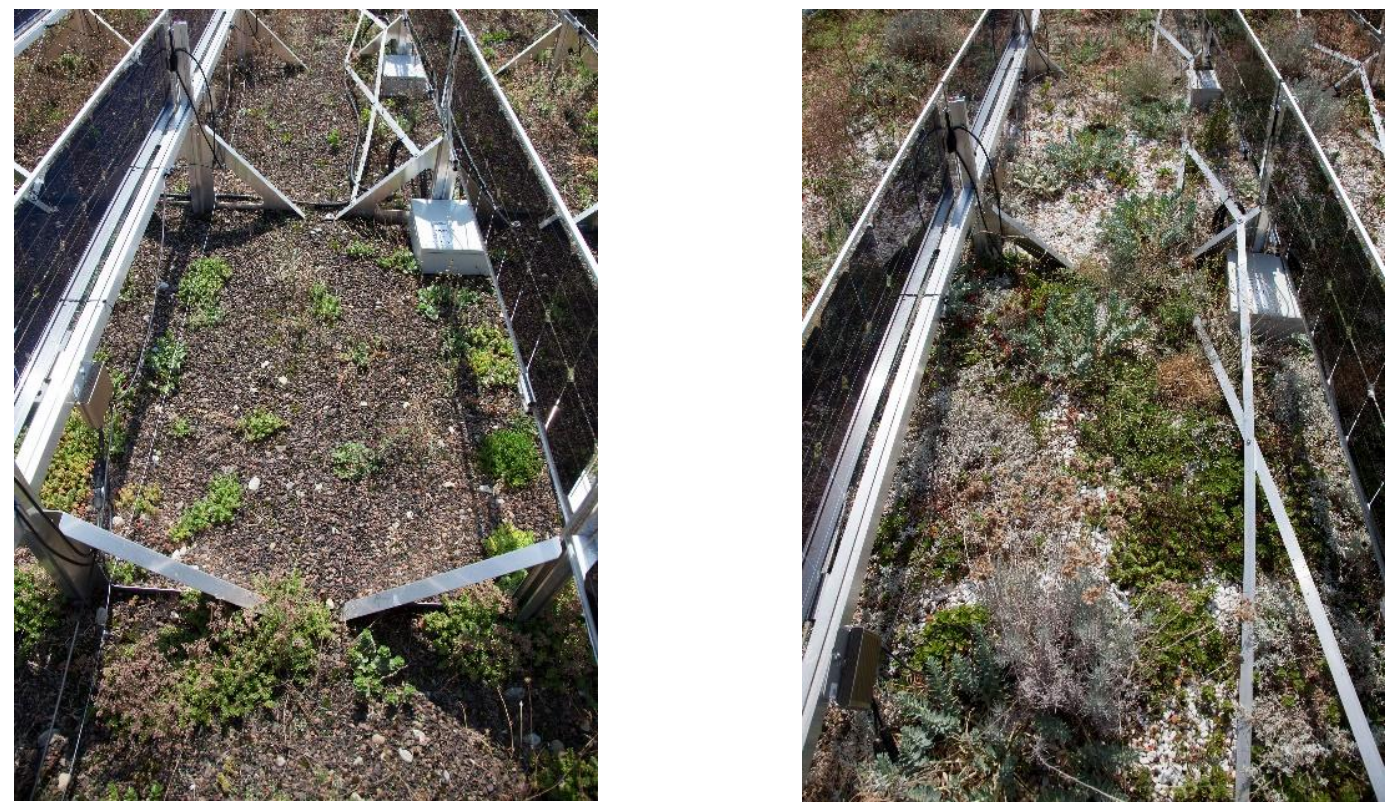

Figure 3 Photos of the two green roof areas that were measured with increased precision. On the left side is the standard green-leaved green roof (SGR) and on the right side is the "bright" silvered-leaved green roof (BGR). The photos were taken after a long dry and hot period on $21^{\text {st }}$ August 2018 . The depictions demonstrate the higher resilience of the silverleaved plants compared to the standard greening. 


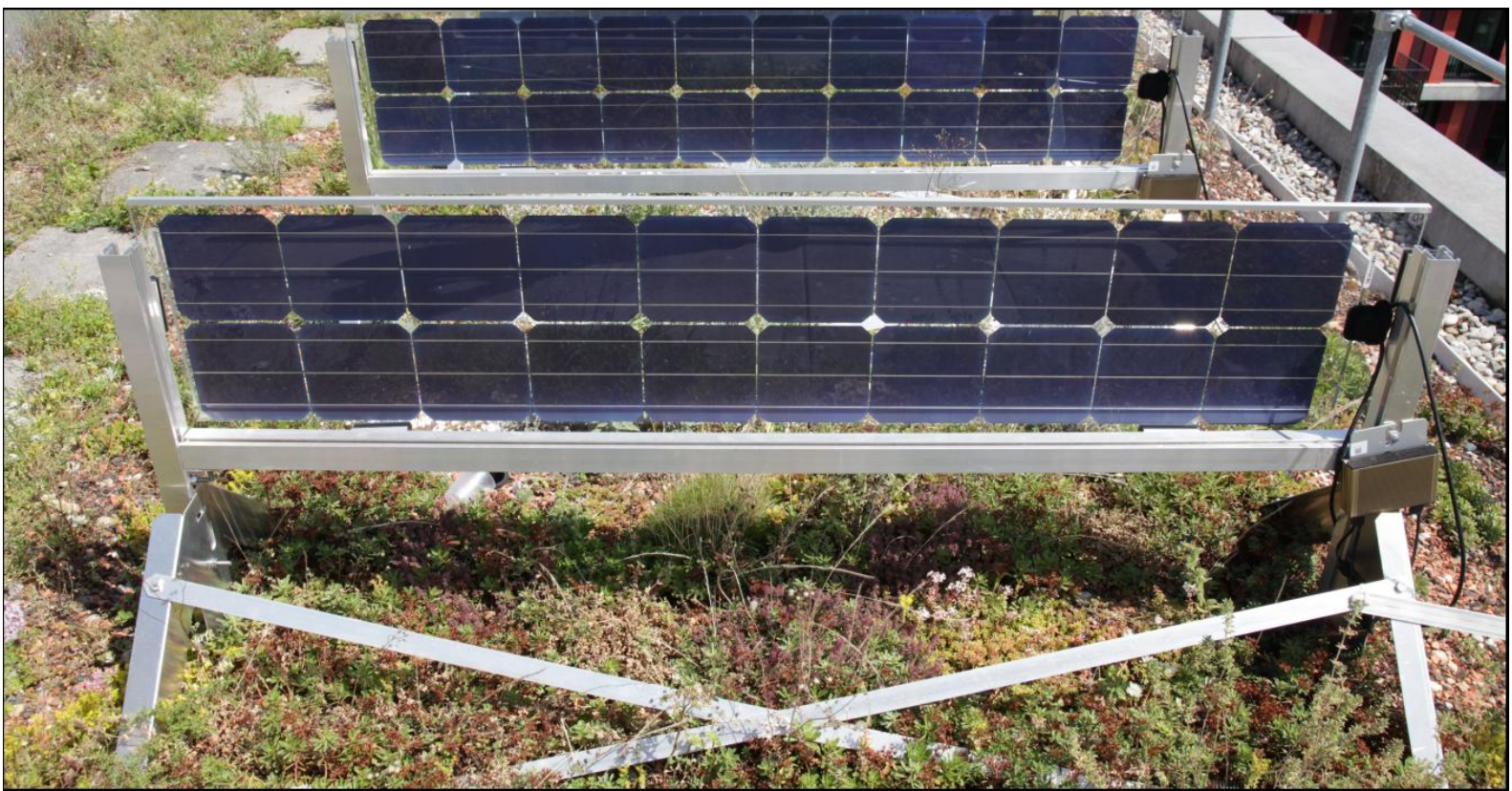

Figure 4 Custom-made module and mounting. The module is a narrow 20 cell bifacial device installed in landscape orientation.

The bifacial modules used for the vertical installation are custom-made glass/glass modules, with 20 monocrystalline n-type silicon "BiSoN" cells from the manufacturer MegaCell. A photo of such a module on an also custom-made mounting system for vertical installation from the company ZinCo is shown in figure 4. The modules have a dimension of $36 \times 170 \mathrm{~cm}$, whereby the cell covered area is $31.5 \times 157.5 \mathrm{~cm}^{2}$ The STC-power of the installed modules was measured in the laboratory with a portable LED Flasher (Knecht et al., 2017). Each side of the bifacial module was measured separately while the other side was completely shaded. At STC-conditions, the modules have a measured front side power of about $82 \mathrm{Wp}$ and a bifaciality factor of about $87 \%$.

The narrow layout of the modules can be beneficial with regard to the optical appearance of the system. It results in a less bulky overall impression of the system compared to installations with vertically installed 60 -cell modules. Due to the reduced wind load, also the mounting substructure can be less massive. In addition, the narrow layout affects the vision angle from below the roof. Related issues are particularly relevant for PV systems in urban areas (Probst and Roecker, 2019) (Florio et al., 2018).

The distance between the ground and the lower edge of the module was chosen to be 40 $\mathrm{cm}$. A certain distance off the ground is necessary in order to avoid shading by plants and the covering by snow in winter. The row distance between the modules is $98 \mathrm{~cm}$, which corresponds to a shading angle of $20.2^{\circ}$ and a ground coverage ratio (GCR) of $36.7 \%$. The row distance was chosen based on the simulations of large, vertically installed 60 cell modules (Nussbaumer et al., 2015). The simulations indicated that for reasonable albedo factors a distance of about three meters (GCR 33\% for landscape orientation) is required to obtain specific annual yields $(\mathrm{kWh} / \mathrm{kWp})$ that are comparable to typical monofacial installations. As the custom-made bifacial modules, which are used in this study, have roughly a third of the width, the row distance can also be reduced to a third. Similar simulations are shown further down in Figure 8. According to these simulations, for an GCR 
of $33 \%$ an albedo factor close to 0.4 is necessary to obtain specific yield parity with an eastwest oriented monofacial system ( $10^{\circ}$ tilt, $100 \%$ GCR, same front side module power).

The south oriented $\left(25^{\circ}\right.$ azimuth, $16^{\circ}$ tilt angle) monofacial reference module is a glass/backsheet module (Hareonsolar type HR-210-24/Aa) with 72 monocrystalline silicon cells.

The test roof is located in Winterthur, Switzerland (coordinates: $47^{\circ} 30^{\prime} 10.7^{\prime \prime} \mathrm{N} 8^{\circ} 43^{\prime} 22.0^{\prime \prime} \mathrm{E}$ ). There is a higher building on the west side of the roof, which causes shading in the evening. Figure 5 shows a panorama photo, including the sun positions over one year. The shading causes more power loss on the bifacial modules than on the reference module. In order to avoid wrong conclusions, only measurement data up to an azimuth angle of $86^{\circ}$ is evaluated. In a complementary evaluation, the missing data from $86^{\circ}$ azimuth onwards were simulated as described below, in order to reconstruct data that would be obtained at unshaded conditions.

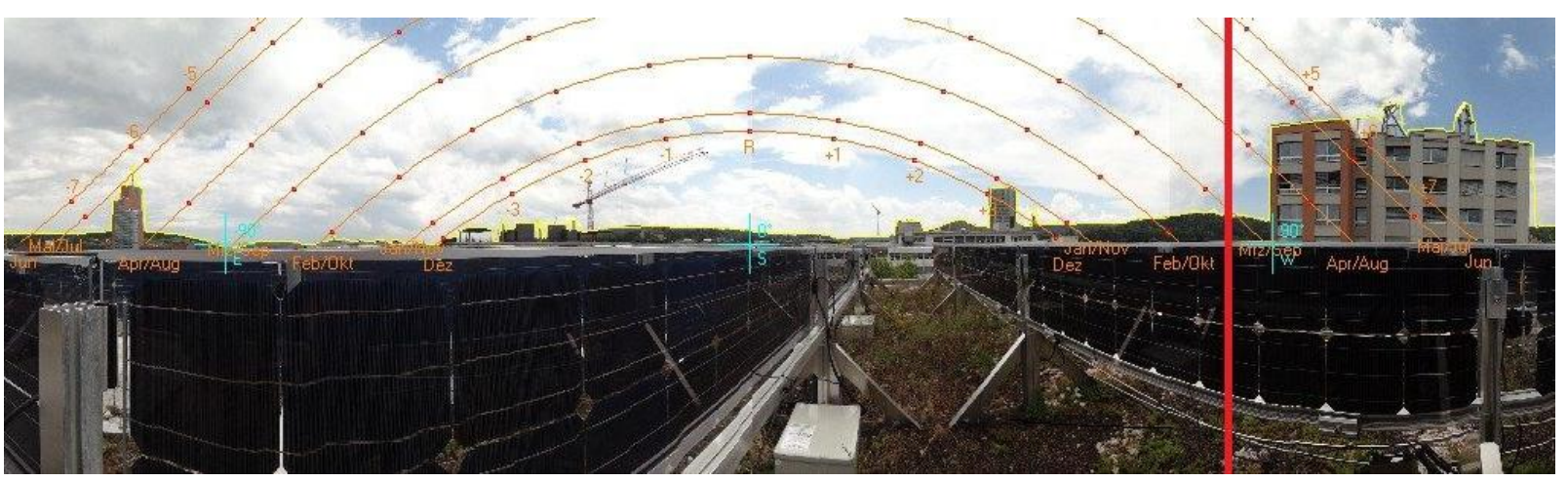

Figure 5 Panorama photo with indicated sun positions. The vertical line marks the $86^{\circ}$ azimuth angle. For angles larger than $86^{\circ}$ a nearby building causes shading of the installation. Therefore, for azimuth angles to the right of the vertical line simulated data is used to complement the data sets.

An albedo measurement, listed in Table 2, was performed on a clear day (21 August 2018) at a sun position of $25^{\circ}$ azimuth. At these conditions, the shadows of the modules were exactly below the modules and did thus not reduce the albedo. The measuring device was placed at the height of the upper edges of the monitored module in the middle of the module rows. Figure 3 and figure 6 show the photos that were taken at the time of the albedo measurement. In order to allow a comparison, the albedo factors of the gravel surface (figure 6 left) and of a SGR area that was less affected (figure 6 right) by the preceding extremely dry conditions were also measured.

The more detailed DC power measurements for the SGR subfield were performed in an area that suffered more and had as a result a lower share of plants covering the ground (figure 3 left). The horizontal global irradiance during the albedo measurements was $780 \mathrm{~W} / \mathrm{m}^{2}$. 

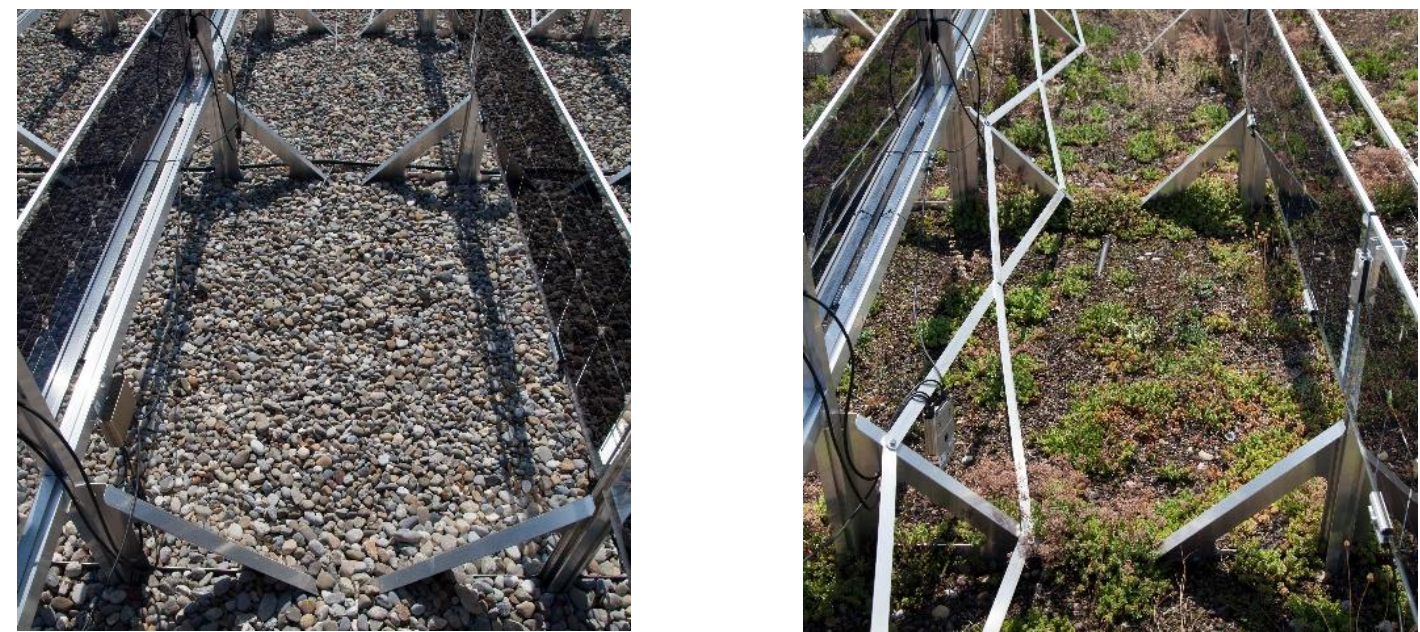

Figure 6 Gravel (left) and standard green roof (SGR) with more plants (right) at the time of the albedo measurements.

Table 2 Results of albedo measurements with different surfaces carried out on $21^{\text {st }}$ August 2018. Measured on the module upper edges in the middle of the module rows.

\begin{tabular}{|l|c|}
\hline Surface & Albedo [ ] \\
\hline SGR (figure 3 left) & 0.09 \\
\hline BGR (figure 3 right) & 0.21 \\
\hline Gravel (figure 6 left) & 0.14 \\
\hline SGR with more plants (figure 6 right) & 0.16 \\
\hline
\end{tabular}

The measured albedo factors in Table 2 show that by means of plants an improvement of the albedo is possible. The standard green roof subfield with a high share of bare soil, in the presented case caused by dry and hot conditions, leads to the lowest albedo factor of 0.09 . For the less affected subfield with more plants, a higher albedo factor of 0.16 is measured. This is almost identical to the value that is measured for the gravel covered area. The highest albedo factor is obtained with the plants with the silvery leaves in BGR subfield.

\section{Energy yield simulations of the realized system and comparison to measured data}

In this study, also PVSyst and MATLAB based simulations were carried out, mainly to complement the measurement data that had to be clipped due to the limited azimuth angle range (see figure 5).

For the simulations, 10-minute meteo data (global irradiance, diffuse irradiance, air temperature, wind speed and wind direction of MeteoSwiss (Federal Office of Meteorology and Climatology) were taken. The data was recorded by a nearby weather station, located in Kloten (14.2 km linear distance). A low-cost irradiance measurement was installed on the test roof itself, but it was also affected by the shading and was therefore not used for the simulation. The yield simulation with MATLAB is structured as follows:

1. Sun position (azimuth and elevation) (DIN 5034-2:1985-02, 1985)

2. Angle of incidence (AOI) (Quaschning, 2013) 
3. Extraterrestrial irradiance (Quaschning, 2013)

4. Direct normal irradiance from global and diffuse irradiance (Quaschning, 2013)

5. Global tilted irradiance (Perez et al., 1990)

6. Low-light performance (Carigiet et al., 2014)

7. Module temperature (Quaschning, 2013)

8. Module power considering low-light performance, module temperature, power temperature coefficient and spectral mismatch (Carigiet et al., 2014)

For the bifacial modules, the global tilted irradiance was calculated for both sides and then summed up to consider the bifaciality. In addition, the mutual shading was taken into account for the calculation of the global tilted irradiance.

In order to obtain a uniform time interval with the 10 second measurement data, the 10 minute simulation data were interpolated linearly (Baumann et al., 2016). The simulated DC power was scaled according to the measurement data prior to the shading and added to the measured data. An exemplary result is shown in figure 7 for one specific day (16 August 2018). The depiction shows the data of the two bifacial modules in the BGR sub-field and the monofacial reference as orange and black lines. For times prior to the clipping, with an azimuth angle lower than $86^{\circ}$, the measured data was plotted. For the shaded conditions with higher azimuth angles the MATLAB simulated data was used.

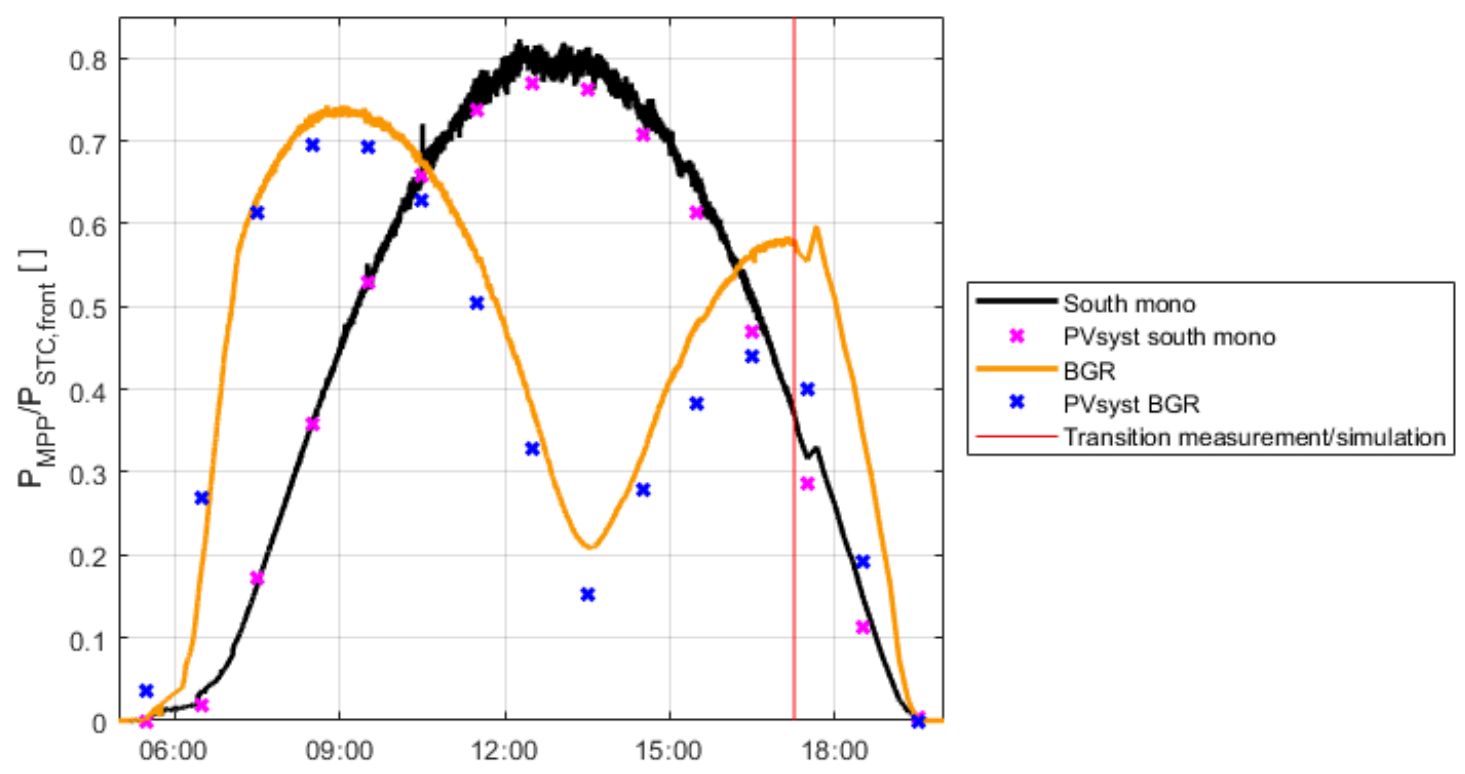

Figure 7 Measured power data for the two bifacial east-west-facing modules (orange) in the BGR sub-field and the south-facing reference module (black) for $16^{\text {th }}$ August 2018 (UTC+1). In order to account for shading, simulated data is added for azimuth angles $>86^{\circ}$ (red vertical line). In addition, simulated data using PVSyst is represented by crosses. The spike close to the transition line is also present in the MeteoSwiss irradiation data and is no simulation artefact.

In addition, also a simulation of the power for the same bifacial modules and the monofacial reference with PVSyst version 6.74 was carried out. Crosses in figure 7 represent the 
resulting hourly values for the two systems. For the specific day shown, the difference in the bifacial system is significant, especially for the second half of the day. The differences cannot be explained by the fact, that the global irradiance values are wrong, since the simulation for the south-facing monofacial module corresponds fairly well to the measured data. Similar PVSyst simulations were carried out for the whole period of measurements, corresponding results and deviations are listed in Table 3.

In Table 3, the specific DC energy yields in $\mathrm{kWh} / \mathrm{kWp}$ for the measured period from $19^{\text {th }}$ May 2018 to $18^{\text {th }}$ September 2018 are shown for the three different cases considered:

- Monofacial, south orientation as reference module ( $25^{\circ}$ azimuth, $16^{\circ}$ tilt angle)

- Bifacial, vertical, East/West oriented; azimuth angle of $-65^{\circ}, \mathrm{SGR}$, ground albedo 0.09

- Bifacial, vertical, East/West oriented; azimuth angle of $-65^{\circ}, \mathrm{BGR}$, ground albedo 0.21

The first row lists the measured data up to $86^{\circ}$ azimuth angle. The second line shows the combination of measured data and simulation beyond $86^{\circ}$ azimuth, in order to compensate shading effects by the nearby building.

Rows three to five show a comparison between measured and simulated data using PVSyst. A certain complication with regard to the comparison of measured data and PVSyst simulations is the use of one-hour steps in the simulation tool. The correct inclusion of the step caused by the $86^{\circ}$ azimuth within a one-hour period is difficult. In order to make the simulated and measured energy yield comparable it is necessary to delete the affected hour that includes the $86^{\circ}$ azimuth angle from the measured and simulated data. The resulting changes due to this approach are represented by the adapted results in rows 3 and 4 , indicated by "measurement $1 \mathrm{~h}$ res". The deviation of the results is respectively shown in row five. The error of the PVSyst simulation is below $5 \%$ for the analyzed period.

Table 3 Specific DC energy yields in $\mathrm{kWh} / \mathrm{kWp}$ for the period from $19^{\text {th }}$ May 2018 to $18^{\text {th }}$ September 2018. The upper two lines reflect the actual energy yield as obtained by the measurements and the complementary simulations. Rows 3 and 4 show adapted data to allow a comparison of measured and PVSyst simulated data. The hour including the $86^{\circ}$ azimuth angle is respectively deleted (" $1 \mathrm{~h}$ resolution").

\begin{tabular}{|c|c|c|c|c|}
\hline Row & $\begin{array}{l}\text { Dataset - } 123 \text { days } \\
19 \text { May to } 18 \text { September } 2018\end{array}$ & 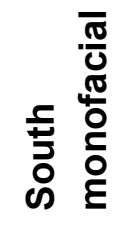 & 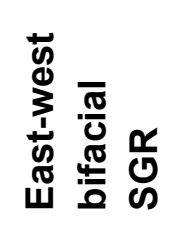 & 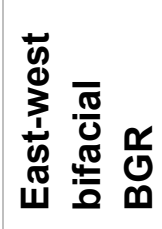 \\
\hline 1 & Measurement $\left(<86^{\circ}\right.$ azimuth angle $)[\mathrm{kWh} / \mathrm{kWp}]$ & 603.2 & 476.3 & 557.9 \\
\hline 2 & $\begin{array}{l}\text { Measurement and complementary simulation } \\
\left.\text { for azimuth angles }>86^{\circ}\right)[\mathrm{kWh} / \mathrm{kWp}]\end{array}$ & 658.7 & 557.4 & 650.0 \\
\hline 3 & Measurement $1 \mathrm{~h}$ resolution $\left(<86^{\circ}\right)[\mathrm{kWh} / \mathrm{kWp}]$ & 577.5 & 452.1 & 529.7 \\
\hline 4 & PVSyst $1 \mathrm{~h}$ resolution $\left(<86^{\circ}\right)[\mathrm{kWh} / \mathrm{kWp}]$ & 597.7 & 471.3 & 515.1 \\
\hline 5 & Deviation of measurement and PVSyst & 3.4 & 4.1 & -2.9 \\
\hline
\end{tabular}


For the two vertical bifacial systems, the bright green roof (BGR) provides a significant increase in yield compared to the standard green roof (SGR). There is a yield increase of $17.1 \%$ for the pure measurement data and of $16.6 \%$ for the measurement with complementary simulation, in order to compensate for the shading.

It has to be mentioned however that the difference in energy yield between the BGR with the reflecting plants and the SGR with the standard greening is overestimated by the results in table 3. The detailed measured SGR sub-field suffered considerably more from the dry and hot summer than other areas with the same plants (compare figures 3 and 7 ). The resulting darker ground in this sub-field caused a pronounced drop of the albedo factor (0.09), compared to the less affected area (0.16), as shown in table 2. Due to the changing conditions of the plants, the albedo was also not constant, throughout the measurement period. Detailed measurements in other SGR areas that suffered less (figure 6) would have shown a higher yield. With regard to the albedo the beneficial effect of the BGR greening with silvery-leaves is two-fold. First, it leads to an increased albedo factor compared to green plants due to higher reflection. Second, the higher resilience of the plants provides a more stable albedo at unfavorable conditions that often prevail at flat roofs.

Comparing the energy yield of east-west bifacial BGR with the south-oriented monofacial module a yield loss of $7.5 \%$ for the time-period from $19^{\text {th }}$ May 2018 to $18^{\text {th }}$ September 2018 had been measured. When considering the energy yield caused by the shading for azimuth angles larger than $86^{\circ}$ the resulting yield loss is reduced to only $1.3 \%$. The obtained specific energy yield $(\mathrm{kWh} / \mathrm{kWp})$ with the BGR system is therefore almost identical to the southoriented, monofacial stand-alone module without mutual shading. Especially in the wintertime, when snow covers the ground, higher albedo values may increase the energy yield significantly, particularly in combination with a reduced snow coverage due to the vertical mounting.

\section{Simulated energy yield data for different system layouts}

Motivated by the tolerable correspondence of the measured and simulated results, we carried out additional simulations in order to obtain general indications on the limits of the energy yield of PV systems using vertically installed PV modules in combination with green roofs. Energy yield data is calculated as a function of the ground cover ratio (GCR) and depending on the albedo. A period of one year is simulated using PVSyst version 6.74. The simulations are based on bifacial and monofacial modules with the same nominal front side power.

In figure 8 , the simulated specific energy yields in $\mathrm{kWh} / \mathrm{kWp}$ of vertical east-west oriented bifacial PV systems with varying GCR and albedo are related to an also simulated typical monofacial installation (bold X). The simulated monofacial installation is east-west oriented with a low tilt angle of respectively $10^{\circ}$ and with a GCR of $100 \%$. This type of east-west oriented modules with a low tilt angle and high GCR is a typical installation type on large flat roofs, which aims at a maximization of the total yield in $\mathrm{kWh}$ by an optimized utilization of the available space. It also has a very small mutual shading due to the low tilt angle. 


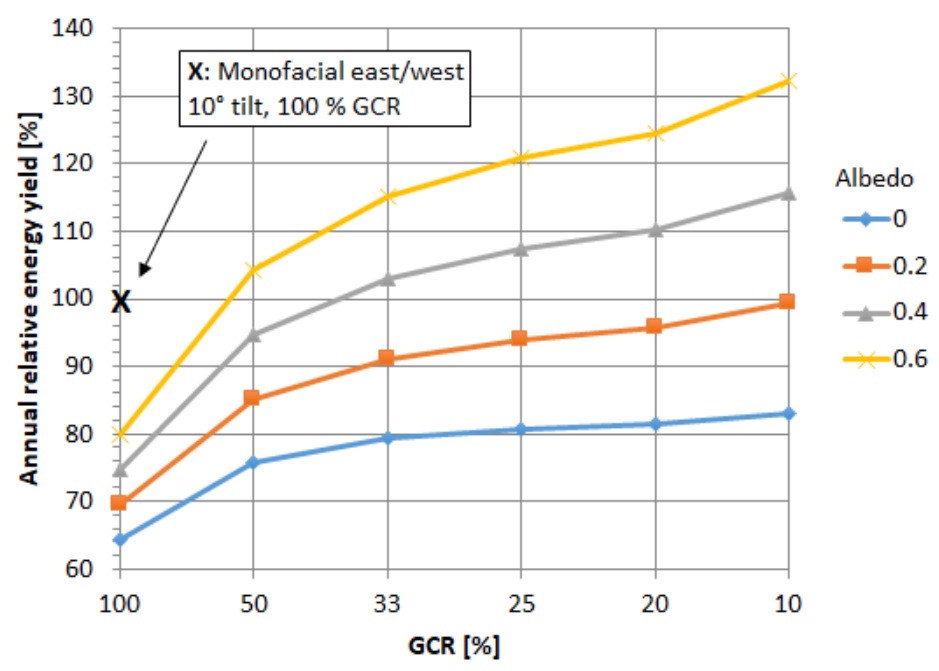

Figure 8 Simulated (PVSyst 6.74) annual relative energy yield (kWh/kWp) of vertical eastwest oriented bifacial PV systems with varying GCR and albedo compared to an also eastwest oriented monofacial installation with $100 \%$ GCR and respectively $10^{\circ}$ tilt angle (bold X).

The simulations indicate that it is possible to obtain specific yields $(\mathrm{kWh} / \mathrm{kWp})$ with vertical bifacial installations that are comparable to the ones of conventional, monofacial installations. It is however also apparent that vertical bifacial installations require a low GCR and high albedo factors to be competitive.

A high albedo factor can be realized in principle by using reflective material on the ground or the selection of favorable locations for example snow covered mountainous areas or deserts. For green roof applications however, the obtainable albedo is limited, even if measures such as the use of plants with silvery leaves are implemented. In addition, the lower GCR that is necessary to limit the losses due to mutual shading causes a lower total output in kWh per available roof area compared to classical monofacial installations. According to Figure 8 a GCR of $33 \%$ an albedo factor close to 0.4 would be required to obtain specific yield parity with the east-west oriented monofacial system. Due to the GCR of $33 \%$ the total yield per area would therefore be a $1 / 3^{\text {rd }}$ of the monofacial example. The specific yield parity could also be obtained with an albedo factor of 0.2 and a GCR of $10 \%$ or an albedo factor of about 0.5 and a GCR of $50 \%$, corresponding to a total yield of $10 \%$ and $50 \%$ compared to the monofacial system.

In spite of these drawbacks, there are also numerous advantages from vertical PV installations in combination with green roofs that were extensively discussed in the above sections.

As complementary information, the results from an also performed simulated height variation for vertical bifacial installations should be mentioned. Surprisingly, the yield difference with increasing installation height from 0 to $1 \mathrm{~m}$ was below $3 \%$ relatively. If proven by measurements this would mean that the installation height for vertically installed bifacial modules is only of minor importance with regard to the energy yield of the system. For regions with little or no snow, the modules could be positioned close to the ground, which could be of practical importance and may result in lower cost for the sub-constructions. 


\section{Conclusion}

PV installations on flat green roofs are an interesting option in several regards, the practical application is however difficult because of goal conflicts. Vertical bifacial systems are a way to avoid such conflicts and to combine the advantages of both approaches. In this work, a system was realized and the output was compared to typical monofacial systems and simulations.

It was shown that vertically mounted bifacial PV systems with east-west orientation can reach specific energy yields $(\mathrm{kWh} / \mathrm{kWp})$ that are comparable to the ones of typical monofacial installations on flat roofs. Despite having some shading and undergrounds with albedos of less than 0.2 , the bifacial installation with a rated power of $9.09 \mathrm{kWp}$ achieved a specific yield of $942 \mathrm{kWh} / \mathrm{kWp}$ in one year. This is close to typical values of $1000 \mathrm{kWh} / \mathrm{kWp}$ achieved for south-facing monofacial systems in the same region.

The output of vertical installations is however heavily dependent on the albedo and the ground cover ratio. It was shown that plants with silvery leaves can improve the system yield to a certain extent compared to standard roof greening. First, it leads to an increased albedo factor compared to green plants due to higher reflection. Second, the higher resilience of the plants provides a more stable albedo at unfavorable conditions that often prevail on flat roofs. Apart from a sufficient albedo, a low ground cover ratio is necessary for vertical bifacial systems to limit losses due to mutual shading. Therefore, the total installed capacity in $\mathrm{kWp}$ per available roof area and the total yield in $\mathrm{kWh}$ for this type of installation is lower than for standard monofacial systems. This is a disadvantage if the goal is a maximized output per available roof space.

Nevertheless, there are also striking advantages of this installation type because it allows the combination of a real green roof and photovoltaics. Roof greening is increasingly recognized and already in demand in some communities in order to lower the negative effects of a cumulative covering with impervious material by artificial structures. It is important for water retention in urban areas and is beneficial with regard to biodiversity and cooling. Due to the vertical installation, the maintenance of the green roofs can be carried out efficiently because the area in between the PV module rows is easily accessible. Maintenance costs may be further reduced by using a mowing robot (Baumann et al., 2016). Due to the east-west orientation of the vertical modules there is a generation profile, which reduces peak generation at noon. Vertical mounting also suppresses soiling effects. In winter, snow covering may be reduced and the yield may even be improved by the high albedo factor of snow. The narrow modules of the presented approach reduce the wind load, which allows less massive sub-constructions and improves the optical appearance. The disadvantage of the lower total yield per roof area is also relativized if one keeps in mind that some national or regional regulations are in favor of a high self-consumption instead of a high feed-in ratio.

\section{Acknowledgement}

Thanks to the founding agency "Klimafonds Stadtwerk Winterthur" and project partners Solarspar, ZinCo, Megasol, Meyer Burger, Fenaco, A777 garden design, Stadtwerk Winterthur (public utility Winterthur), Swiss professional association for green buildings SFG, ZHAW Life Sciences and Facility Management. Thanks to the management of the retirement home Wiesengrund, which supported the project on their roof and to Hanspeter Willi (head housing technology) for the technical assistance. 


\section{References}

Azeñas, V., Cuxart, J., Picos, R., Medrano, H., Simó, G., López-Grifol, A., Gulías, J., 2018. Thermal regulation capacity of a green roof system in the mediterranean region: The effects of vegetation and irrigation level. Energy and Buildings 164, 226-238. https://doi.org/10.1016/j.enbuild.2018.01.010

Baumann, T., Carigiet, F., Knecht, R., Klenk, M., Dreisiebner, A., Nussbaumer, H., Baumgartner, F.P., 2018. Performance Analysis of Vertically Mounted Bifacial PV Modules on Green Roof System, in: 35th European Photovoltaic Solar Energy Conference and Exhibition. Presented at the 35th European Photovoltaic Solar Energy Conference and Exhibition, WIP/EUPVSEC, Brussels.

Baumann, T., Schär, D., Carigiet, F., Dreisiebner, A., Baumgartner, F., 2016. Performance Analysis of PV Green Roof Systems, in: 32nd European Photovoltaic Solar Energy Conference and Exhibition; 1618-1622. Presented at the EUPVSEC, WIP/EUPVSEC. https://doi.org/10.4229/EUPVSEC20162016-5CO.14.3

Carigiet, F., Baumgartner, F.P., Sutterlueti, J., Allet, N., Pezzotti, M., Haller, J., 2014. Energy Rating Based on Thermal Modelling of Five Different PV Technologies, in: 29th European Photovoltaic Solar Energy Conference and Exhibition; 3311-3315. Presented at the EUPVSEC, WIP/EUPVSEC. https://doi.org/10.4229/eupvsec20142014-5cv.2.34

DIN 5034-2:1985-02 Tageslicht in Innenräumen; Grundlagen, 1985.

Florio, P., Probst, M.C.M., Schüler, A., Roecker, C., Scartezzini, J.L., 2018. Assessing visibility in multi-scale urban planning: A contribution to a method enhancing social acceptability of solar energy in cities. Solar Energy, 173, 97-109. https://doi.org/10.1016/j.solener.2018.07.059

Francis, L.F.M., Jensen, M.B., 2017. Benefits of green roofs: A systematic review of the evidence for three ecosystem services. Urban Forestry \& Urban Greening 28, 167176. https://doi.org/10.1016/j.ufug.2017.10.015

Guo, S., Walsh, T.M., Peters, M., 2013. Vertically mounted bifacial photovoltaic modules: A global analysis. Energy 61, 447-454. https://doi.org/10.1016/j.energy.2013.08.040

Knecht, R., Baumgartner, F., Carigiet, F., Frei, C., Beglinger, F., Zaaiman, W., Pavanello, D., Field, M., Galleano, R., Sample, T., 2017. Field Testing of Portable LED Flasher for Nominal Power Measurements of PV-Modules On-Site, in: 33rd European Photovoltaic Solar Energy Conference and Exhibition; 2007-2012. Presented at the 33rd European Photovoltaic Solar Energy Conference and Exhibition, WIP/EUPVSEC. https://doi.org/10.4229/EUPVSEC20172017-6C0.15.1

Muntwiler, U., Schott, T., Kuonen, F., Lanz, M., Schüpbach, E., Sigrist, H., Ellenberger, B., Amrein-Gerber, H.R., Probst, T., Harlacher, C., Hinter, S., Dreisiebner, A., Beck, A., Wassman-Takigawa, F., 2019. Photovoltaik + Vegetation auf Dach und Fassade: gewusst wie!, poster presentation at the 17. Nationale Photovoltaik-Tagung, Bern

Nussbaumer, H., Klenk, M., Schär, D., Baumann, T., Carigiet, F., Keller, N., Baumgartner, F.P., 2015. PV Installations Based on Vertically Mounted Bifacial Modules Evaluation of Energy Yield and Shading Effects, in: 31st European Photovoltaic Solar Energy Conference and Exhibition; 2037-2041. Presented at the EUPVSEC, WIP/EUPVSEC. https://doi.org/10.4229/EUPVSEC20152015-5AV.6.34 
Perez, R., Ineichen, P., Seals, R., Michalsky, J., Stewart, R., 1990. Modeling daylight availability and irradiance components from direct and global irradiance. Solar Energy 44, 271-289. https://doi.org/10.1016/0038-092X(90)90055-H

Probst, M.C.M., Roecker, C., 2019. Criteria and policies to master the visual impact of solar systems in urban environments: The LESO-QSV method. Solar Energy 184, 672-687. https://doi.org/10.1016/j.solener.2019.03.031

PVsyst Photovoltaic Software [WWW Document], n.d. URL http://www.pvsyst.com/en/ (accessed 10.12.18).

Quaschning, V., 2013. Regenerative Energiesysteme: Technologie - Berechnung Simulation, 8., aktualisierte und erw. Aufl. ed. Hanser, München.

Snow, J., 2016. Green Roofs Take Root Around the World [WWW Document]. National Geographic News. URL https://news.nationalgeographic.com/2016/10/san-franciscogreen-roof-law/ (accessed 3.5.18).

Soukup, M., Häne, S., 2015. Mit grünen Dächern gegen die Hitze. Tages-Anzeiger. 